\title{
Perspective of Islamic Education on Reproductive Health in Senior High School Students (Study at Senior High School in Mataram City - NTB)
}

\author{
Wahab $^{1}$, Mustolehudin ${ }^{2}$ \\ \{wahab.alba@gmail.com ${ }^{1}$, mustolehuddin@gmail.com ${ }^{2}$ \} \\ Religious Research, Development and Training Agency, Ministry of Religious Affairs, Jakarta, \\ Indonesia (Badan Penelitian dan Pengembangan dan Pendidikan dan Pelatihan, Kementerian Agama, \\ Jakarta, Indonesia) $)^{1,2}$
}

\begin{abstract}
Reproductive health education for senior high school adolescents is important. Students in senior high school in West Nusa Tenggara (NTB), which incidentally are a city of thousand mosques, are interesting to give in-depth study. The findings obtained through research using mix method. Education on reproduction can teach through the subject of Biology and PAI (Islamic religious education). Related to reproduction organs, the most of students in senior high school in NTB, especially in SMA N 3, SMA N 4 , and SMA N 7, they understand reproductive organs both biologically and according to Islamic religious education perspective.
\end{abstract}

Keywords: Students of Senior High school, Adolescent Health, Reproduction, West Nusa Tenggara.

\section{Introduction}

According to UNESCO, reproductive health education is an education developed with an age-appropriate, cultural-sensitive and comprehensive approach including programs that contain accurate, realistic and non-judgmental scientific information. Comprehensive reproductive health education provides an opportunity for adolescents to explore the values, attitudes, and practice in decision making, communication and risk suppression skills in all aspects of sexuality. One aspect that children need to know on healthy reproduction is: positive aspects of sexuality that is sex must consider the norms, social values, and gender inequality [1].

Discussing sex always relates to humans. Humans are born with the potential and sexual instinct towards the opposite sex, regardless of the various sexual deviations (paraphilia). Sex is, basically, a natural or instinctive need of living things to carry on life and preserve generation, either found in humans and other living creatures. Sex education for adolescents is an effective way of education to provide insight, guidance, and prevention for adolescents in dealing with sexual problems that occur at their age and how to manage their emotions. At this point, the urgency of education containing morality is internalized early, according to individual development. Morality-oriented education is also involved in sex education with an Islamic education approach. Islam emphasizes that the problem of reproduction (sex) needs to be managed according to religious teaching guidance, for example 
through marriage, fasting, hold the gaze, and so on. When compared to other countries such as Germany and the Netherlands, the implementation of sex education in Indonesia is not comprehensive yet.

Sex education might state as not been widely implemented within the scope of formal learning in educational institutions. In reality, sex education is more integrated (insertion) in certain subjects and programs than specific subjects. The obstacle might relate to psychological factors, educational policy, and the readiness of human resource. Based on the background, this paper seeks to present the concepts and ideas of sex education to adolescents from the perspective of Islamic education.

In line with the background, the formulation of the problems are; 1) How is the implementation of reproductive health education (Kespro) at senior high schools in Mataram?; 2) How are the students' understanding toward reproductive health (Kespro) viewed from an Islamic perspective ?; 3) What are the factors support and inhibit reproductive health education (Kespro) in the perspective of Islam?

\section{Literature review}

Since 1970, sex education in the West (as in Germany) has included in the curriculum which consists of growth processes, changes in body shape, emotions, biological and reproductive processes, social activities, partnerships, homosexuality, premarital pregnancy, complications from abortion, danger of sexual violence, sexual violence in children, infectious diseases caused by sexual relations, sexual positions, and contraceptives. In the Netherlands, sex education began in the late 1980s through the Long Live Love package. Through this package, the government provides the youth with the ability and knowledge to make decisions about health and sexuality [2].

At this point, Islam, as a religion that upholds the balance of world orientation and the hereafter, plays a role in framing and directing the sexual instincts of mankind through the sources of the teachings in the Quran and the Sunnah of the prophet to achieve the harmony with god's rules. Islam exists neither as a restraint nor kills the sex. Moreover, Islam provides guidance and rules on how sexual behavior has positive benefits and values (worship value). Guidance and rules are interpreted as sex education. Sex education from an Islamic perspective certainly has differences from the Western perspective. But, both of them also have similarities to complete each other [3].

Uthman ath-Thawiil defines sexual education as giving lessons and understanding to boys and girls starting they enter the age (baligh) and being frank with them about issues relating to sex, instincts, and marriage. Anshori LAL interpreted sex education according to Islam as education that teaches material about marriage under the framework of religious teachings.

Another definition of sex education was argued by an Islamic education expert, Abdullah Nashih Ulwan which argued the sex education is an effort to teach, awareness and information about sexual problems given to children since they understand issues relating to sex, instincts, and marriage.

The previous various meanings of sex education have similarities, namely education related to sexuality issues and those related to them given by adults to the younger generation (early age, adolescence, and adults) following the religious, Islamic, moral and health 
framework. This definition also illustrates that sex education is comprehensive and relates to monotheism (one god), worship, and morals [4].

\section{Research method}

The particular study used qualitative and qualitative approaches, commonly known as mixed methods or combinations. Cresswel, in Sugiyono [5] stated that a combination method is a research approach that combines quantitative and qualitative research methods. Furthermore, Cresswel stated that there are two kinds of combination models, namely: (1) the concurrent triangulation model (a balanced mix of qualitative and qualitative) and (2) concurrent embedded (an unbalanced mix of quantitative and qualitative). The model used in this study was the first model (concurrent triangulation model) [6]. The subjects were SMAN 3, SMAN 4, and SMAN 7, in Mataram City, West Nusa Tenggara. Data collection techniques were in-depth interviews, observations, documentation, and questionnaires.

\section{Result and discussion}

\subsection{Description of social and religious of the school environment}

Mataram is the capital of the Province of West Nusa Tenggara (NTB) that becomes an international-scale tourist destination. The reality is illustrated by the huge number of domestic and foreign tourists visiting a lot of tourist attractions area in NTB province, such as waterfalls, beaches, protected forests, mountains, and so on.

Tourist places are almost entirely located in the area of Lombok Barat, Lombok Timur, Lombok Tengah, and Lombok Utara. However, most tourists stay in the hotel in Mataram because are still rarely found international-class hotels outside Mataram. Also, there are many places of entertainment near tourist sites, such as karaoke and cafes.

The Governor of NTB (TGB Zaenul Majdi) is seen by the community as quite successful in developing tourist areas in this region. As areas of tourist destination in Indonesia, the visit of domestic and foreign tourists led to the occurrence of cultural acculturation between the cultures of local people and culture from outside (bring by the tourist). Then, it perhaps, influences the lifestyle and behavior of the people of NTB, especially the people in the City of Mataram.

The Governor's policy on the development of tourism in this province which aims to overcome the occurrence of moral decadence within the community is by creating the slogan "NTB is a Sharia tourism destination." The slogan was conveyed by several interviewees of this research, such as principals, teachers, official of Ministry of Education and Culture, an official of Ministry of Religion, and students of senior high school who were the objects of this study. Examples of policies on Sharia tourism are that each hotel is advised to provide facilities for worship in hospitality (prayer mats, holy books, and Qibla direction), prohibitions on performing performances with crowds at prayer times, and must pause it during worship, and so on.

The consequences as an area which are experiencing the world tourism development, the social conditions of the people of Mataram City, in particular, nowadays cannot be avoided from the interactions with tourists, considering that NTB is a rapidly growing tourist destination and is known to the world. Social interaction between the local community and 
tourists directly or indirectly affects the behavior of the community, especially the younger generation, in this case, the students of senior high school.

Realizing the reality of the development of the world of tourism in the region (NTB), especially in Mataram, the principals with their respective teacher have made policies in a preventive effort for their students to tackle the negative affected by tourist culture that is not in accordance with the culture of the community in NTB, which is religious. These policies are not only implemented internally by the school, but also build partnerships with external parties, such as the Health Office, BKKBN (National Population and Family Planning Board), BNN (national anti-narcotics agency), and Satpol PP (Civil Service Police Unit).

In addition to assisting the UKS (School Health Clinic) activities, the Partnership with the Health Office is, incidentally at a certain time, to provide information on general health issues as well as reproductive health. Also, the BKKN is intended to disseminate information about family welfare and, more specifically, also related to reproductive health for families.

Then, the partnership with BNN is an effort by schools to provide information about the dangers of drugs and ways to prevent them. Therefore, the competent party for this business is BNN. This way, the school works together with BNN to provide well understanding among students on narcotics and juvenile delinquency. Moreover, the partnership with Satpol PP aims to monitor the students if they are found in malls and places in the city during the learning hours.

Then, by the religious conditions among the three high schools, described the following explanation. The location of SMAN 3 and SMAN 4 Mataram is in the middle of the city, while SMAN 7 is located near the edge of the city towards the Senggigi beach recreation area. The three high schools are geographically located in the Mataram as the capital of NTB, known as the earth of a thousand mosques. The name of the city reflects how religious the people of Mataram.

Considering the description of the environmental conditions of the people of Mataram also has implications for religious life in the objects of this study. Each of these schools is religiously Islamic, which is running lively with various religious activities at the school. According to the explanations of the principals, the strengthening of religiosity is an effort for students not to fall into negative behavior. The principals and teachers added, the religiosity activity was not only implemented at school, but, in their family and community environment, students also participate in religious activities, such as reciting the Quran in the afternoon and at night, and recitation (teaching) or ta'mir assemblies.

\subsection{Implementation of reproductive health education in SMAN 3, SMAN 4 and SMAN 7}

\section{Mataram}

The implementation of reproductive health education in the three Mataram senior high schools (SMAN 3, SMAN 4, and SMAN 7) is not much different because, among teachers of biology, PAI (Islamic religious education) and BK (Guidance and Counseling) in delivering material are always guided by the curriculum 2013. While, the differences in the implementation, each teacher has the method in exploring the contents of the reproductive health learning material that is addressed to students, such as there are biology teachers who are rather vulgar when explaining reproductive organs, in contrast, there are teachers who are 
very careful in delivering the material. Likewise, some PAI teachers are vulgar when delivering adultery or marriage materials, but, some teachers have only followed the curriculum without providing illustrations relating to reproduction.

In reproductive health learning activities, both biology and Islamic education teachers use teaching aids and LCDs. Nevertheless, they show only limited to human organs (biology) and full ablution (a person in such a state needs to take a bath in order to become ritually pure and be able to perform his prayers after do the sexual intercourse or seminal discharge) and adultery according to Islam. The learning methods of reproductive health education materials are quite varied, such as lecturing, questions and answers, practices, and discussions. According to the teachers both biology and PAI teachers, the discussion of this material was quite interesting for students and even quite responsive when discussing the material.

The response of enthusiasm in the discussion of this material was more visible in male students, while female students looked timid to discuss. But, in fact, some female students personally consult directly to biology and PAI teachers.

\subsection{Implementation of learning in the field of biological studies}

Learning activities in the field of biological studies on reproductive topics for class $\mathrm{XI}$ are $12 \times 45$ minutes at the 31 st and 32nd meetings. And, the standard of competence is to explain the structure and function of certain human and animal organs, abnormalities/diseases that occur in the human reproductive system. Whereas, the basic competency is to explain the interrelationship among structure, function, and process which includes the development of genital cells, ovulation, menstruation, fertility, pregnancy, and breastfeeding as well as abnormalities/diseases that occur in the human reproductive system.

The purpose of learning on reproduction materials in class XI of senior high school students in face-to-face activities 31 and 32 meetings, is that students can describe the structure, function, processes and abnormalities/diseases that occur in the reproductive system. Indicators of achieving competency in reproductive learning are students can: (1) identify structures, functions, and processes that occur in the male reproductive organs, (2) identify the structures, functions, and processes that occur in female reproductive organs, (3) describe the process fertility and pregnancy, (4) connecting contraception and the process of preventing pregnancy in family planning, (5) identifying abnormalities that occur in the human reproductive system, and (6) identifying the animal's reproductive system.

Based on the learning objectives of reproductive material, the teaching materials for class XI high school students are; (1) the structure of male reproductive organs, (2) the structure of the female reproductive organs, (3) the process of oogenesis and ovulation, (4) the process of spermatogenesis, (5) fertility and pregnancy, (6) family planning technology, and (7) abnormalities / diseases that occur in the human reproductive system.

The steps taken by the teacher in learning at the core stage are the teacher exploring images of male reproductive organs and students are asked to identify the parts and functions. Next, the steps in the elaboration stage are: (1) the teacher and students discuss the process of spermatogenesis and hormones in the process, (2) the teacher gives an image of the female reproductive organs, then asks students to identify the parts and its functions, (3) students and teachers discuss the process of spermatogenesis and ovulation, (4) students and teachers discuss the menstrual cycle, (5) students and teachers discuss menstrual cycles and hormones that affect the process, and (6) by looking the structure of the female organs reproduction, 
students are asked to describe the process of fertilization and the process of pregnancy in women.

Furthermore, at the confirmation stage, the teacher concludes the unknown things yet and explains them. The final learning activities are: (1) students and teachers conclude the male and female reproductive systems, spermatogenesis and oogenesis processes, menstrual cycles, fertilization, and pregnancy, (2) teachers and students pray together, and (3) teachers and students say hello to each other (source of lesson plan arranged by the third biology teacher at senior high school as the object of this study).

Core Competencies (KI3) of this material are students of understanding, applying, analyzing and evaluating the factual, conceptual, procedural, and metacognitive knowledge based on curiosity about the knowledge, technology, art, culture, and humanities with the insight of human, national, state, and civilization related to the causes of phenomena and events, and apply procedural knowledge to specific fields of study in accordance with talents and interests to solve problems. Whereas, the Core Competencies (KI4) are students to process, reason, present and create in the realm of concrete and abstract domains related to the development of what they learn in school independently and to act effectively and creatively, and able to use methods according to scientific principles.

Basic Competence of knowledge by giving reproductive material to students on class $\mathrm{XI}$ is that students are able to analyze the relationship of the structure of the reproductive organs with its functions in the human reproductive system, by the Competency Achievement Indicators (IPK) are: (1) Identifying the structure of male reproductive organs, (2) identifying the structure of female reproductive organs, (3) explaining the function of the male reproductive organs, (4) explaining the functions of the female reproductive organs, (5) explaining the process of spermatogenesis and oogenesis, (6) explaining mechanism of ovulation and menstruation, (7) explaining the accuracy of ovulation period, (8) explaining the abnormalities in the structure and function of organs properly, (9) analyzing the application of the principle of reproduction in humans and giving exclusive breastfeeding in family planning programs as an effort to improve the quality of human resources (SDM), (10) explaining the benefits of exclusive breastfeeding for quality of SDM, (11) explaining the purpose of the KB (Family's planning) program, and (12) Identifying the types of contraception.

Basic competence skills by giving reproductive material to students on class XI is that students are able to: (1) present the analysis results from the impact of promiscuity, disease, and abnormalities on the structure and function of organs that cause disruption of the human reproductive system and reproductive system technology, (2) compiling reports the impact of promiscuity with diseases and abnormalities in the structure and function of the reproductive organs as well as the reproductive system technology, (3) presenting papers on the importance of preparing a planned generation to improve the quality of human resources (HR), (4) explaining the factors lead to an increase in the number of people, (5) identifying the types of diseases on the reproductive system, and (6) describing the ways to care for the health of reproductive organs.

The purpose of giving reproductive material in class XI is that through learning activities with a scientific approach using cooperative learning models, students can analyze the relationship between the structure of the reproductive organ network structure and its function in the human reproductive system and analyze the application of the reproduction to humans and exclusive breastfeeding in family programs planning as an effort to improve the human resources (HR). And, they able to present the analysis results of the effects of promiscuity, disease and structural disorders and functions of the reproductive organs and the 
importance of preparing a planned generation to improve human resources. Thus, it grows the awareness of students of the greatness of God, disciplined behavior, honest, active, responsive, polite, responsible, and work together.

Learning material for reproductive health is related to: (1) the structure and function of reproductive organs in male and female, (2) the process of spermatogenesis and oogenesis, (3) ovulation and menstruation, (4) fertilization, gastric and childbirth, (5) ASI (breast-milk), (6) KB (Family's planning), and (7) Disorders / diseases related to the reproductive system.

A biology teacher in reproduction learning activities also explains in detail the definitions and/or terms in the material that "reproduction" in humans occurs sexually, meaning that the individuals begin with the unity the sperm and egg. The human reproductive system is divided into male and female reproductive organs. So, students know the function of reproductive organs both male and female reproductive organs.

\subsection{Learning on Islamic education}

In Islamic education, the learning materials of the reproductive health among on the third senior high school are adultery and marriage. Material for adultery by educators explains the norms of relations between men and women who are not Muhrim (family members or relatives who are forbidden to marry each other (i.e siblings, mother, and child, etc) is Haram (forbidden or proscribed by Islamic law). That fact has already explained in the Quran. The innovation of educators in this material that, young people usually been dating, but, educators explain that, in Islam, there is teaching not to approach adultery. Therefore, dating certainly will lead to lust, among from the eyes, hands, and even further the reproductive organs of both male and female. When they cannot do self-control, then, it has already been small adultery, such as kissing, hugging, and even more dangerous to make love (have a sex like husband and wife); those include in adultery).

Learning materials of marriage are usually taught in class 12 that the goal aims the students understand the definition and types of marriage, law, goals, rules, and conditions of marriage in Islamic law and things that cancel the marriage, the rights, and obligations of husband and wife, and the wisdom of marriage in Islamic law. Learning on marriage material is expected the students able to demonstrate the procedures for implementing marriages in Islamic law.

The learning method applied by educators in learning is through a scientific and religious approach, the strategy is with cooperative learning, group learning, and lecturing. The media for teaching are laptops, LCDs, whiteboards, and worksheet. Whereas, the teaching source is the learning book of PAI and Budi Pekerti (ethic) on grade XII at the curriculum 2013.

The purpose of learning material in building the household (marriage) under the Islamic law for high school students is that students are hoped to understand the definition and types of marriage, law, goals, rules, and terms of marriage in Islamic law and things that cancel the marriage, the rights and obligations of the husband-wife and wisdom of marriage in Islamic law. And, at the end of learning, students can demonstrate the procedures for implementing marriage in Islamic law.

Learning materials for the marriage are: 1) Definition of marriage; 2) Marriage law; 3) Proposals for marriage advice; 4) The purpose of marriage; 5) Rules and conditions of Marriage; 6) Rights and obligations in marriage; 7) Things that cancel the wedding; 8) Types of marriages in Islamic law; and 9) Marriage wisdom. 
Implementation of learning materials in building household (marriage) according to Islamic law in high school, the learning approaches used by teachers are scientific and religious, and cooperative learning strategies with methods of questions and answers, study groups, and lecturing. The learning media are slides, power points, laptops, LCDs, whiteboards and worksheet.

The core activity, the teacher first asks students to open the books of PAI and Budi Pekerti in the marriage chapter. Then, the teacher asks students to observe the prepared pictures and raise several questions to students as well as providing reinforcement/refinement of student answers. And, finally, the teacher explains briefly the definition of marriage in terms of language and terms.

The next activity, the teachers divide students into 4 groups in the class and gives different themes between groups to discuss. After that, the students require to record the important points being discussed. Then, each group representative presents the results of the group discussion in turn. And, the teacher asks students to gather a summary of the results of the discussion. At the end of the discussion activity, the teacher gives an appreciation of the learning process. Those are the process of learning material in building household (marriage) at meetings I, II and III (Source: Lesson plan arranged by teachers of Islamic education at SMAN 3, SMAN 4, and SMAN 7 Mataram, 2018).

\subsection{The role of the guidance and counseling (BK) teacher in reproductive education}

The role of the Guidance and Counseling (BK) teacher in reproductive health education in the three objects of this study (SMAN 3, SMAN 4, and SMAN 7) is not only limited to providing advice, input, and guidance on students' behavior at school. Moreover, the implementation of the guidance not only occur when there are cases on students, but, the guidance and counseling teachers have an important role in efforts to build the personality of students in schools and, also, reproductive health education.

The guidance and counseling teachers in the three schools stated that the implementation of counseling on reproductive health can be known through in-depth interviews, and during the learning. The teacher also explained that reproductive health according to WHO (World Health Organization) is an intact state of physical, mental and social, not only free from disease or disability in all aspects related to the reproductive system, its functions and processes, or a condition in which humans can enjoy sexual life and can carry out the reproductive functions and processes in a healthy and safe manner.

The teacher also explained that humans, since birth, are completed with reproductive organs, namely organs that function to produce generation. The reproductive organs are different between male and female. The term reproduction comes from the word "re" which means kembali/back and "production" which means to make or produce. So, the term "reproduction" has the meaning of human life in producing generation for the sake of descent and the preservation of life. The core material of reproduction delivered by guidance and counseling teachers is not much different from the material provided by biology teachers. The differences, the material provided between biology teacher and BK teachers is that biology teachers are more detailed, while the material given by BK teachers is more on general material.

Then, the materials given by the guidance and counseling teacher who has relevance to adolescence are; 
1. Adolescence is divided into three phases, namely: (1) early adolescence (approximation age 11 to 13 years), middle adolescence (approximation age 14 to 17 years), and late adolescence (approximation age 17 to 19 years).

2. Physical growth in female adolescent, namely: (1) starting menstruation, (2) improved breasts and buttocks, (3) enlarged ovaries, (4) oily skin and hair, and grow acne, (5) vaginal discharge, 6) growing hair in armpits and around the vagina, and (7) increasing the height of body.

3. Physical growth in male adolescent, namely: (1) louder and steady the voice, (2) growing hair in armpits and around genitals, (3) growing a mustache, (4) experiencing nocturnal orgasm, ( 5) growing Adam's apple, (6) getting bigger and broader the shoulders and chest, and (7) growing the penis and testicles.

4. Psychological changes, both in male and female, such as emotions, thoughts, feelings, social environment, and responsibilities, namely: (1) teenagers prefer to gather outside the home with their groups, (2) teenagers more often argue or violate the rules of parents, (3) adolescents want to show and/or even introvert, and (4) adolescents do not consider or become very dependent on the group (source RPK BK teacher on High School as the research object in 2018).

Thus, the role of the guidance and counseling teacher does not specifically convey the material on reproductive health in detail, but the material is more general with elaboration on teenage material. Besides, the guidance and counseling teacher has a stake in the activities related to counseling, disseminating information on reproductive health from agencies that have tasks related to reproductive functions, such as the Office of Health, BKKBN, and BNN.

\subsection{The understanding of students on senior high school against reproductive health viewed from a religious perspective}

The indicators of the religiosity characteristics among the three high schools (SMAN3, SMAN 4, and SMAN 7 in Mataram) are seen from 6 aspects. First, the majority of students proved that they often perform the obligatory prayers 5 times a day, with the highest answer choices were "often" of $88.33 \%$. Second, the majority of students sometimes do the Sunnah prayer before or after the obligatory prayer, with the highest answer choice was "sometimes" of $70 \%$. Third, the majority of students sometimes follow activities in the mosque/Musholla (prayer room other than mosques in Indonesia) besides the obligatory prayers, proved by the highest answer choice was "sometimes" of $56.67 \%$. Fourth, the majority of students have never joined the youth organization of the mosque/Musholla, proved by the highest answer choice was "never" of $43.33 \%$. Fifth, the majority of students have never joined a religious organization in a school (Rohis), proved by the highest answer choice was "never" of $45 \%$. Sixth, the majority of students sometimes attend religious activities in schools other than Rohis, such as PHBI (commemoration of Islamic holidays), Eid al-Qurban, etc., proved by the highest answer choices were "sometimes" of $85 \%$.

Furthermore, indicators of student understanding and behavior on reproductive organs are seen in 5 aspects. 1) The majority of students understand that every human being has a reproductive organs that has maturity in a certain period of time, proved by the highest answer choice was "understanding" of $53.33 \%$; 2) The majority of students understand that if the reproductive organs have not yet matured period, there will be a risk of damage in sexual acts or sexual intercourse, proved by the highest answer choice was "understanding" of $35 \%$. 3) The majority of students understand that if do intercourse at the immature age of the 
reproductive organs will result in a pregnancy, proved by the highest answer choice was "understanding" of $45 \%$ and "very understanding" of $41.66 \%$. 4) The majority of students understand that free sex will make the damage to the reproductive organs and cause infectious diseases, proved by the highest answer choice was "very understanding" of $50 \%$ and "understands" of $40 \%$. 5) The majority of students very understand that premarital sex is a behavior that violates the norms of religion and society, proved by the highest answer choice was "very understanding of $80 \%$.

Indicators of students' understanding of reproductive health in the perspective of Islam in three senior high schools (SMAN 3, SMAN 4, and SMAN 7) are seen in 7 aspects. First, the majority of students very understand that the reproductive organs are human nature given by Allah SWT (God The Almighty), then, in using them must refer to religious teachings, proved by the highest answer choice was "very understanding" of $65 \%$. Second, the majority of students very understand that free sex behavior (same-sex and/or opposite-sex) will damage the reproductive organs and violate the religious norms, proved by the highest answer choice was "very understanding" of $63 \%$. Third, the majority of students very understand that premarital sex not only violates the norms of the society but also violates religious norms, proved by the highest answer choice was "very understanding" of $76.67 \%$. Fourth, the majority of students very understand that premarital sex will lead to pregnancy (KTD) and prohibited in religion, proved by the highest answer choice was "very understanding" of $63.33 \%$. Fifth, the majority of students very understand that premarital sex will lead to pregnancy (KTD) and is prohibited in religion, proved by the highest answer choice was "very understanding" of $65 \%$. Sixth, the majority of students understand that the use of contraceptives for premarital age is an act violating the religious norms, proved by the highest answer choice was "understanding" of $38.33 \%$ and "very understanding" of $35 \%$. Seventh, the majority of students very understand that the function of reproductive organs religiously and nationally legitimate way is part of prevention of reproductive health, proved by the highest answer choice was "very understanding" of $53.33 \%$ and "understanding" of 38 , $33 \%$.

And, indicators of students' understanding of Reproductive Health in the PAI curriculum are seen from 3 aspects. First, the majority of students very understand that reproductive health has been taught in Islamic Religious Education subjects, proved by the highest answer choice was "very understanding" of $45 \%$ and "understanding" of $40 \%$. Second, the majority of students understand the frequency of providing the teaching of reproductive health education in Islamic Religious Education subjects, proved by the highest answer choice was "understanding" of $46.67 \%$ and "very understanding" of $25 \%$. Third, the majority of students do not understand that, in learning reproductive health education, the teacher of Islamic Religious Education use certain media, proved by the highest answer choice was "not understanding" and "poor of understanding" of $29.33 \%$.

\subsection{Factors supporting reproductive health education}

Supporting factors for reproductive health education in the perspective of Islam is the policies from principals with sufficient attention related to reproductive health education. This fact was proven by the collaboration with the Health Office, BKKBN, BNN, PKK of NTB Province, Satpol PP, and religious leaders to disseminate information about youth and reproductive health. 
Besides the previous factors, the school also provided the opportunity to send 5 students to follow the activities organized by the PKK of NTB Province which is about early marriage, reproductive health, and drugs. Then, the quite important of supporting factor is the seriousness attitude of the teachers in the fields of biology, PAI, and BK especially those who intensively provide understanding to students, both during class and outside class with individual student consultations.

Another important supporting factor is also the implementation of reproductive health in the three objects of this study (SMAN 3, SMAN 4, and SMAN 7 Mataram), that the majority of students are Muslim, and then, the teachers are more likely to provide illustrations from Islamic teachings view. Therefore, for biology teachers, in particular, they are more freely exploring reproductive material which links with the norms of Islamic teachings.

There is a small obstacle for biology teachers when the people (teachers) whose religion is different from the majority of students. Considering that the people of Mataram City are predominantly adherents of strong Islamic religion and a strong social religious, then the teacher must be extra careful when giving learning material reproduction so as not to offend students whose social environment is known to be religious (Islam). Also, specifically PAI teachers, they in learning activities have not optimally used learning media that have relevance to reproductive health material.

\subsection{Implementation of reproductive health education}

Implementation of reproductive health education among the three objects of the study (SMAN 3, SMAN 4, and SMAN 7 Mataram), in real terms, is the most dominant provided through biology studies. That fact supported by materials of reproduction is involved in the curriculum of biology studies.

Learning reproduction material which is in class XI, discusses a lot about the male and female reproductive organs completing with its elements, definition terms, functions, the process of sex cells, ovulation and menstruation, fertilization, gastric and childbirth, related disorders / diseases with the reproductive system and even about family planning and breastfeeding. The learning in reproduction material in students of class XI at high school aims, the students can describe the structure, function, and processes and abnormalities/diseases that can occur in the reproductive system.

The objectives show that the implementation of reproductive health education, especially on senior high school, the target of the research is more likely to provide textual material from curriculum 2013, which is related to the structure, function, and abnormalities that might occur in reproductive organs. According to the biology teachers at three schools (SMAN 3, SMAN 4, and SMAN 7 Mataram), the learning are not all of them thoroughly explored the reproduction material, because, the teacher is required to complete the material in accordance with curriculum guidelines so that the delivery of the material can only be fulfilled following the targets as stated in the curriculum.

They have made an effort to deliver reproductive material following the curriculum guidelines. But, it does not mean that the teachers are only following the curriculum, in fact, the teachers must also elaborate with the other related materials obtained through print and electronic media. Using open-source materials obtained from various media will make the teacher having more knowledge when explaining reproductive health material to students. 
Thus, the implementation of reproductive health learning in the three high schools in Mataram is in line with the curriculum 2013 for reproductive education for high school students, especially through biology. Whereas, in the study of Islamic Religious Education (PAI) and Guidance Counseling (BK), reproductive health education is more strengthening the knowledge and understanding of Islamic norms and student behavior norms. It concluded that the implementation of reproductive health education in three research objects (SMAN 3, SMAN 4, and Mataram High School) is sufficient to provide knowledge of reproduction to students.

\subsection{Students' understanding of reproductive health}

Students' understanding of reproductive health through Islamic Religious Education is seen by several indicators, namely: (1) the characteristics of student religiosity, (2) background of student, (3) background of parent, (4) residence, ( 5) adolescent behavior related to reproductive organs, (6) reproductive health in the perspective of the Islamic religion, (7) students' understanding of reproductive health in the PAI curriculum, (8) students' perceptions toward the interaction in school, and (9) supporting factors for sexual deviant behavior.

\subsection{Characteristics of student religiosity}

The characteristics of the student religiosity are viewed from the aspect of worship which is in an adequate good category, proved by the frequency of the performing the obligatory five-time prayer; only a small portion (only occasionally) or $11.67 \%$ (7 students). Meanwhile, almost all students stated that they perform the five-time obligatory prayers regularly. Furthermore, the majority of students only occasionally perform the Sunnah Ba'diyah and Qabliyah prayers.

Then, the majority of students among the three schools only occasionally participated in mosque activities, mostly they never attended activities of Remaja Masjid (mosque youth organization), mostly they never attended an activity of religious organizations in the school (Rohis), and mostly they only occasionally sometimes attend religious activities at school.

Thus, concluded that the students among the three high schools states as obedient in performing the five-time prayer, but, it still needs improvement on religious activities. The step is a certain way to further strengthen the religiosity of students who are not merely performing the worship. Because by being active in religious activities will increase students' religious knowledge and understanding which will also impact on their behavior.

\subsection{Adolescent behavior related to reproductive organ}

Most of the students in senior high school, in this research object, have understood that every human being has a reproductive organ that has a maturity at a certain time. But, there are still students who lack understanding and even do not understand.

Most of the students among SMAN 3, SMAN 4, and SMAN 7 Mataram have already understood when the reproductive organs have not yet matured; there will be a risk of damage involving in sexual acts or sexual intercourse. Meanwhile, there a lot of numbers of students who lack understanding and even do not understand. 
Most of the students at senior high school, in this research object, understand when having intercourse at the age of immature, the reproductive organs will lead to pregnancy. Moreover, sadly, found out that some students lack and even do not understand.

The students in senior high school, mostly, understand that free sex with the opposite sex will damage the reproductive organs and cause infectious diseases. But, there are some students lack and even do not understand.

Most of the students in senior high school, in this research object, understand that engaging in premarital sex is a behavior that violates the norms of religion and society. Moreover, sadly, found out that some students lack and even do not understand.

Based on students' answers related to understanding and behavior about the reproductive organs showed that many students lack and do not understand needs to get serious attention from school. Moreover, there might be a possibility of a negative impact on students. Also, students lack and do not understand can affect their friends who understand in their daily interactions at school or outside of school. Therefore, the school should try to complete the understanding and behavior of students to understand well the reproduction organ.

\subsection{Reproductive health in the perspective of the Islamic religion}

Most of the students of SMAN 3, SMAN 4, and SMAN 7 Mataram already fully understand and understand that the reproduction organ is human nature given by Allah SWT, so the function is regulated under teachings of Islam. There are still some students lack and even do not understand that the reproductive organ is human nature given by Allah SWT, then the function is regulated under Islamic teaching. Thus, there is attention from PAI teacher to further strengthen the learning process related to reproduction, which discusses adultery in class $\mathrm{X}$ and discuss marriage in class XII.

PAI teachers do not have specific tasks related to reproductive organ material in a biological perspective, but, in a religious normative perspective, of course, they must provide an understanding of religious norms related to reproductive behavior. Thus, PAI teachers are required to be able to collaborate and explore the material of adultery and marriage with reproduction.

Based on the answers of students as the respondents showed that most of the students answered very understanding and understanding free sex behavior (same-sex and/or opposite sex) would damage the reproductive organs and violate the religious norms. In fact, there are still some students lacking and even do not understand that free sex behavior (same-sex and/or opposite sex) will damage the reproductive organs and violate religious norms. In this aspect, PAI teacher also still should complete aiming the students will understand it.

The students among three senior high schools (SMAN 3, SMAN 4, and SMAN 7 Mataram) were mostly very understanding and understanding that having premarital sex not only violated the norms of the society but also violated religious norms. And, proved by some students are still lack and even do not understand this aspect. Therefore, PAI teachers also still have the responsibility to provide understanding to students.

Related to the understanding of reproductive health in the perspective of Islam, most of the students already understand and even strongly understand that sexual intercourse outside marriage is very vulnerable to the occurrence of sexually transmitted diseases (STDs) 
and violate the religious norms. Nevertheless, it turns out that some students are lack and even do not understand this aspect. Therefore, for PAI teachers need to teach and provide reinforcement to improve the understanding of reproductive health, especially regarding sex outside marriage, to students who lack and do not understand.

Most of the students of SMAN 3, SMAN 4, and SMAN 7 Mataram had understood that the use of contraceptives for premarital age was an act violating the religious norms. But, there are still some students who need extra attention from PAI teachers to understand about the use of contraceptives following the perspective of Islamic religious norms.

Most of the students have understood the function of reproductive organs legally and religiously which is part of maintaining reproductive health. In contrast, some students showed a lack and even do not understand the function of reproductive organs legally and religiously which is part of maintaining reproductive health. It is quite dangerous when the PAI teacher does not complete the students' understanding related to this aspect. There might be a possibility of some of the students have sex with the view that having sex is a biological need and not limited by any norm, or depend on love each other.

Considering the students' understanding among three schools (SMAN 3, SMAN 4, and SMAN 7 Mataram) as previously discussed shows that reproductive health in the perspective of the Islamic religion is quite encouraging. Means, most of the students already understand about reproduction health according to Islamic teachings. In fact, the teacher must consider the students who still do not and even do not understand the concept.

Indicators of reproductive health in the perspective of Islam are seen from 7 aspects, namely: (1) reproductive organs are human nature given by Allah SWT, then, the function is regulated in religious teachings, (2) free sex behavior (same-sex and/or opposite sex) will damage the reproductive organs and violate the religious norms, (3) engaging in premarital sex not only violates community norms but also violates religious norms, (4) engaging in premarital sex will lead to pregnancies (KTD) and prohibited in religion, (5) sexual intercourse outside marriage is very vulnerable to the occurrence of sexually transmitted diseases (STDs) and violating the religious norms, (6) the use of contraceptives for premarital age is an act violating the religious norms, and (7) using the reproductive organs religiously and nationally legitimate way is part of maintaining the reproductive health.

The seven aspects are representations of the things that have relevance to reproduction and function of reproductive organs that are commonly known among the community, especially teenagers. Discussion on reproduction and function of reproductive organs is linked to Islamic religious norms. Based on the results, most of the students have already understood the reproductive health in perspective of Islam. This fact relates to the socio-religious conditions of the people in Mataram, known as religious communities.

The students in senior high school live in a religious socio-cultural (Islam) in families, communities, and schools. Islamic religious activities in the family and the environment of the students are strong capital to fortify the behavior of moral decadence. The activities are learning the Islamic knowledge or reading the Quran at home or in mosques, majelis ta'lim and so on still, that all the activities color the Islamic religious life in the city. Those certainly have an impact on student behavior, especially behavior relating to reproductive. Also, it was strengthened by various religions that were followed by students in the schools. So, by the Islamic religious knowledge from family, community, and school life students understand reproductive health from the perspective of the Islamic religion. 


\subsection{Students' understanding of reproductive health in the PAI curriculum}

Most of the students at SMAN 3, SMAN 4, and SMAN 7 Mataram have understood that reproductive health is taught in Islamic Religious Education subjects, which is adultery in class X and marriage in class XII. Nevertheless, the students stated that the PAI teacher in delivery the religious material on adultery and marriage also linked to reproduction. For example, the material of ethics subject on social interaction norm according to Islam, on the learning of faith in the creation of humans sometimes also talks about reproduction.

According to the students' perspectives previously mentioned, the frequency of providing material on reproductive health education in Islamic Religious Education subjects is mostly still lack. The material related to reproduction is quite complex, therefore, students hope the PAI teachers not only convey material in normative (according to Sharia only) but should also elaborate with biological reproduction and the development of the world of information technology. Thus, the elaboration makes it easier for students to understand which limit the scope of reproduction material, whether the things are allowed and not allowed according to Islamic Sharia (interview to students on 21, 23, 24 March 2018). Also, according to students' perspectives that PAI teachers have not used relevant media in learning on reproduction, proved by most of the students stated poor and even did not understand why PAI teachers do not use supporting media to support the learning on reproduction material.

\subsection{Students' perceptions of interaction in school}

The results of this study indicated that most of the students of SMAN 3, SMAN 4, and SMAN 7 Mataram understand the khalwat or being together between men and women who are not mahram (blood relationship) is prohibited in Islam. Thus, they understand that the khalwat is prohibited according to the teachings of Islam. Also, the students' understanding is not only obtained from PAI learning at school, but students have also understanding from the family (parents) and participating in the majelis ta'lim held in the surrounding of home. Some students stated that there were no friends who were dating at school due to prohibited by school rules.

Then, related to the introductory process (Ta'aruf) for prospective couples in Islam, the students partially answered very understand. Ta'aruf, according to the results of interviews with several students, is a process for every man and woman who has the intention to get married soon following the Islamic rule. In PAI learning, the material is often explained by the teacher that for a Muslim who wants to get married should be through the Ta'aruf process not through dating as a common way for young people today to get to know one another (men and women). Furthermore, in Islamic teachings, most of the students understand the khitbah (proposal) as a process for men and women to go to marriage. Although in a small portion of the NTB community in general and Mataram in particular, there live tradition of "Merari" before marriage, but, in the perspective of the students, they disagree to this tradition. In fact, a few years ago (in 2013), there were students who were married using Merarik tradition and had to leave school before passing the final exam. 


\subsection{Supporting factors for sexual deviance behavior}

Socio-economic and demographic factors, according to the perspective of students of SMAN 3, SMAN 4, and SMAN 7 Mataram, influence sexual deviance behavior. Most of the students stated that poverty, low levels of education, ignorance of sexual development and processes, and remote locations or places of residence, might impact sexual deviance behavior. Almost all students stated "right" that the socio-economic and demographic factors influence the sexual deviance behavior. Also, almost all students stated "right" that sexual deviation was caused by lack of information about the function of the reproductive organs.

\subsection{The factors of cultural, environmental, psychological, and biological}

Supporting factors for sexual deviance behavior might be influenced by cultural and environmental conditions. The culture of the environment is such the tradition of shamanism tradition and the tradition of Merarik marriage (in NTB). Almost all students have a perspective and stated "right" that cultural and environmental factors influence on sexual deviance behavior.

Psychological conditions as a factor of sexual deviance behavior are seen by parental relationships and depression due to damage to reproductive organs. Most of the students of SMAN 3, SMAN 4, and SMAN 7 Mataram had perspectives and stated "right" that both aspects could psychologically influence the sexual deviance behavior. Then, the students also have the perspective that biological factors can also cause sexual deviance behavior. Psychological factors, here, are seen from two aspects, namely the damage of reproductive organ and/or birth defects in the reproductive tract caused by sexually transmitted diseases. Here, almost all students stated "right" that both aspects can lead to sexual deviance behavior.

\subsection{Factors supporting reproductive health education}

The policy taken by Principal of each SMAN 3, SMAN 4, and SMAN 7 Mataram is important of supporting factor in the implementation of reproductive health education in the perspective of Islam. This fact is from its policy of providing the flexibility of teachers to explore the learning of reproductive health, such as collaborating with parties who have relevance and competence in the field of reproduction and youth.

Not only providing flexibility for teachers to establish partnerships with related parties, but the Principal also agreed to send students to participate in reproductive and drug seminar activities that routinely organized by PKK NTB Province, by sending 5 students each day. Also, in schools, religious and youth activities are held routine to prevent students from sexual deviance behavior and juvenile delinquency. 


\section{References}

[1] P. N. Shintyadita, Putu Noni. 2015. Pentingnya Pendidikan Kesehatan Reproduksi Dan Seksual Pada Remaja. http://www.kisara.or.id/artikel/pentingnya-pendidikan-kesehatan-reproduksidan-seksual-pada-remaja.html . diakses pada tanggal 20 September (2018)

[2] L. Anshori, 2012. Pendidikan Islam Transformatif. Jakarta: Referensi. Pp. 94-95. Referensi, Jakarta (2012)

[3] S. Mujtabah, and M.S. Ridwan, Nikmatnya Seks Islami, p. 18. Penerbit Pustaka Marwa, Yogyakarta (2010)

[4] A. N. Ulwan and H. Hathout, Pendidikan Anak Menurut Islam: Pendidikan Seks, terj. Khalilullah Ahmas Masjkur Hakim dan Jalaluddin Rakhmat, pp. ix. Remaja Rosdakarya, Bandung (1992)

[5] Sugiyono, Metode Penelitian Pendidikan Pendekatan Kuantitatif, Kualitatif, dan R\&D. pp. 1920. Alfabeta, Bandung (2014)

[6] A. Akbar, Seksualitas Ditinjau dari Hukum Islam, Ghalia Indonesia,Jakarta (1983)

[7] A. A. Basyir, Ajaran Islam tentang Pendidikan Seks, Hidup Berumah Tangga, Pendidikan Anak, Al-Ma"earif, Bandung (1996)

[8] Desmita, Psikologi Perkembangan, Remaja Rosdarkarya, Bandung (2008)

[9] Fathurrofiq, Sexual Quotient, Remaja Rosadakarya, Bandung (2014)

[10] J. M. Halstead and R. Michael, Sex Education Nilai dalam Pendidikan Seks Bagi Remaja; Dari Prinsip ke Praktek, terj. Kuni Khairun Nisak, Alenia Press, Yogyakarta (2004)

[11] A. F. Helmi, and P. Ira, "Efektivitas Pendidikan Seksual Dini dalam Meningkatkan Pengetahuan Perilaku Seksual Sehat", Jurnal Psikologi, Fakultas Psikologi Universitas Gadjah Mada., Volume 25 Nomor 21998.

[12] F. Kusuma, Sensasi Remaja di Masa Puber, Kalam Mulia, Jakarta (2003)

[13] R.P. Masland, and E. David, Apa yang Ingin Diketahui Remaja tentang Seks, terj. Mira T. Windy, PT. Bumi Aksara, Jakarta (2000)

[14] Mubin dan A. Cahyadi, Psikologi Perkembangan. Ciputat: Quantum Teaching. (2006)

[15] H. J. Muchtar, Fikih Pendidikan. Bandung: Remaja Rosdakarya. (2008)

[16] Mujiburrahman, Bercermin ke Barat: Pendidikan Islam Antara Ajaran dan Kenyataan. Banjarmasin: Jendela. (2013)

[17] Nuryadin, Pendidikan Reproduksi (Seks) Pada Remaja; Perspektif Pendidikan Islam. Jurnal Studi Agama dan Masyarakat Volum 12 Nomor 1 (2016)

[18] F. M. Rahbar, 1999. Selamatkan Putra-Putrimu dari Lingkungan Tidak Islami, terj. Kamdani, Yogyakarta: Mitra Pustaka. (1999)

[19] M. Roqib, M., "Pendidikan Seks pada Anak Usia Dini”, Insania; Jurnal Pemikiran Alternatif Pendidikan, P3M STAIN Purwokerto., Volume 13 Nomor 2 Mei-Agustus 2008.

[20] M. U. Sa abah, Perilaku Seks Menyimpang dan Seksualitas Kontemporer Umat Islam. Yogyakarta: UII Press. (2001)

[21] B. A. Tanjung, Free Sex No! Nikah Yes!. Jakarta: Amzah (2007) 
[22] M. Thalib, Bimbingan Kemesraan dan Seksualitas Islami. Yogyakarta: Pro-U Media. (2008)

[23] U. Thawiil, Ajaran Islam tentang Fenomena Seksual, terj. Saefuddin Zuhri, Jakarta: PT. Raja Grafindo Persada, (1997)

[24] M. H. Ahmas, dan R. Jalaluddin, pp. ix. Remaja Rosdakarya, Bandung (1992)

[25] A. N. Ulwan, Tarbiyatu '1-Aulad fi 'i-Islam, terj. Saifullah Kamalie dan Hery Noer Aly, Semarang: Asy-Syifa ${ }^{e e}$, (1993) 